Jurnal Pemberdayaan: Publikasi Hasil Pengabdian kepada Masyarakat

Vol. 3, No. 2, Agustus 2019, Hal. 159-172

ISSN: 2580-2569; e-ISSN: 2656-0542

DOI: https://doi.org/10.12928/jp.v3i2.885

\title{
Tech for Kids sebagai pelatihan pengenalan proses perancangan rekayasa di SMPN 11 Tanjung Pinang
}

\author{
Deny Nusyirwan, Toni Suhendra, M.Abyan Fadillah, Oskar Indra Saputra \\ Jurusan Teknik Elektro, Fakultas Teknik, Universitas Maritim Raja Ali Haji \\ Jl. Politeknik Senggarang, Tanjungpinang 29115 \\ Email : denynusyirwan@umrah.ac.id
}

\begin{abstract}
ABSTRAK
Teknologi informasi dan telekomunikasi telah berkembang dengan pesat untuk mendukung digitalisasi di dunia industri. Untuk mendukung hal tersebut, maka jurusan teknik elektro Universitas Maritim Raja Ali Haji melalui tech for kids berusaha meningkatkan kemampuan sumber daya manusia dengan memberikan pelatihan proses perancangan rekayasa. Adapun tujuan dari pelatihan ini adalah untuk memberikan kemampuan teknis dan non teknis kepada siswa di sekolah dasar dan menengah di daerah pesisir dan perbatasan untuk mampu bersaing secara global di era industri 4.0. Metode pendekatan dalam pelatihan adalah partisipatif, dimana mahasiswa sebagai fasilisator bersama siswa aktif berinteraksi untuk menghasilkan luaran berupa rancangan purwarupa digital. Tahapan perancangan yang diperkenalkan kepada siswa dimulai dengan etnografi, untuk melatih siswa dan siswi dalam melakukan observasi terhadap lingkungan sekitarnya, cuurahan gagasan permasalahan yang ditemukan, menentukan solusi utama dari permasalahan utama. Selanjutnya di terjemahkan pada sketsa gambar dan dilanjutkan ke purwarupa vitual. Dari hasil kegiatan Tech for Kids siswa mengalami peningkatan didalam kemampuan menggambar teknik hasil sketsa menggunakan perangkat lunak Autodesk inventor. Selain itu, tech for kids mampu menciptakan suasana belajar yang kreatif, kritis dalam menganalisa dan mampu bekerjasama dengan rekan satu kelompok yang merupakan bagian terintegrasi untuk pola pembelajaran di sekolah masa depan.
\end{abstract}

Kata kunci : belajar, perancangan, rekayasa, siswa, teknologi

\begin{abstract}
Information and telecommunications technology has developed rapidly to support digitalization in the industrial world. To support this, the electrical engineering department at the Raja Ali Haji Maritime University through technology for kids seeks to improve the ability of human resources by providing training in the engineering design process. The purpose of this training is to provide technical and non-technical skills to students in primary and secondary schools in coastal and border areas to be able to compete globally in the industrial era 4.0. The method of approach in training is participatory, where students as facilitators with students actively interact to produce outcomes in the form of digital prototype designs. The design stages that are introduced to students begin with ethnography, to train students and students in observing the surrounding environment, cuuu ideas of the problems found, determine the main solutions of the main problems. Subsequently translated into sketches of images and proceed to vitual prototype. From the results of the Tech for Kids activities students have increased in the ability to draw the results of sketching techniques using the Autodesk Inventor software. In addition, tech for kids is able to create an atmosphere of learning that is creative, critical in analyzing and able to work with teammates as an integrated part of future learning patterns in schools.
\end{abstract}

Keyword : learning, design, engineering, student, technology 


\section{PENDAHULUAN}

Saat ini peneliti mengidentifikasi bahwa pengenalan pendidikan untuk bidang rekayasa di sekolah menengah adalah periode penting untuk meningkatkan kesadaran dan peminatan siswa tentang rekayasa sebagai jalur karir. Oleh karena itu, diperlukan sebuah pendekatan yang diharapkan dapat memperkenalkan proses rekayasa pada periode tersebut, yaitu dengan mengintegrasikan proses perancangan rekayasa untuk dapat menjadi salah satu komponen pada kurikulum di sekolah menengah (Windl et. al, 2019). Selain itu juga perlu melatih pola pikir layaknya rekayasawan dengan memberikan permasalahan-permasalahan yang menantang, sehingga istilah engineering is not for me tidak akan muncul (Lucas dan Hanson, 2016). Peranan penting bagi ilmuwan pada abad ke-21 adalah berperan serta dalam mendidik masyarakat tentang metode dan hasil proses ilmiah (Kastner dan Knight, 2017).

Dari hasil observasi yang dilakukan di sekolah dasar dan menengah di kota Tanjung Pinang, ditemukan minat siswa terhadap teknologi cukup tinggi. Hal ini dibuktikan dengan banyak siswa yang hadir ketika pengenalan teknologi ke sekolah-sekolah. Untuk mendukung minat siswa tersebut, maka jurusan teknik elektro Universitas Maritim Raja Ali Haji (UMRAH) Tanjungpinang melihat perlunya pendampingan didalam memberikan penguatan kemampuan penguasaan teknologi dan menumbuhkan pola pikir seorang rekayasawan pada usia dini melalui sebuah pelatihan yang dinamakan Tech for Kids.

Tech for Kids (TFK) adalah merupakan kegiatan pengenalan proses perancangan rekayasa pada siswa dengan memperkenalkan teknologi dan rekayasa menggunakan pendekatan yang sederhana dan bersahabat, dengan tujuan untuk dapat menumbuhkan minat siswa terhadap rekayasa, dengan cara melatih para siswa untuk mampu bekerja sama, berpikir kreatif dan memahami proses untuk menghasilkan inovasi teknologi yang merupakan solusi yang tepat bagi permasalahan di lingkungannya.

Selain itu, TFK juga menerapkan pola pendampingan selama pelatihan berlangsung, dengan meminta bantuan dari para mahasiswa yang disebut sebagai fasilisator untuk berinterakasi langsung dengan siswa dan siswi SD/SMP selama proses pelatihan berlangsung. Dalam program TFK ini, pemberian motivasi, membangkitkan rasa ingin tau mengenai teknologi dan pendekatan secara emosional kepada para siswa sangat diperlukan untuk menimbulkan minat para siswa mengenal proses rekayasa. Materi-materi dasar akan diberikan pada pertemuan awal dan selanjutnya mengarahkan siswa melakukan observasi untuk dapat menemukan permasalahan-permasalahan di lingkungan sekolah. Adapun pada tahapan selanjutnya para siswa akan menentukan satu permasalahan utama, dan dengan pola curahan gagasan para siswa akan diminta kembali berdiskusi untuk memberikan solusi-solusi, pola pelatihan ini disebut divergent and convergent concept.

Siswa akan diminta untuk menggambarkan sebuah solusi utama terlebih dahulu diatas kertas dan selanjutnya akan didesain menggunakan perangkat lunak autodesk inventor, proses menggambar menggunakan komputer untuk dapat menghasilkan rancangan dinamakan purwarupa virtual, yang merupakan satu bagian dari proses perancangan rekayasa.

Adapun tujuan ahir dari pengabdian adalah memberikan penguatan kepribadian dan akademik siswa dengan menciptakan suasana belajar yang kreatif, kritis dalam menganalisa dan mampu bekerjasama dengan rekan satu kelompok yang merupakan bagian terintegrasi untuk pola pembelajaran di era revolusi industri 4.0.

Penulisan ini dimulai dengan informasi dari beberapa pola pengajaran proses desain rekayasa yang telah diterapkan pada beberapa sekolah dasar dan menengah. Selanjutnya penjelasan mengenai metodelogi TFK yang dilaksanakan di sekolah dasar atau menengah di Tanjungpinang. 


\section{George Lucas Education Foundation (GEF)}

George Lucas Education Foundation (GEF) adalah merupakan sebuah lembaga pendidikan untuk anak tingkat sekolah dasar yang didirikan oleh George Lucas pada tahun 1991 sebagai satu bentuk usaha untuk menghasilkan siswa yang kreatif, inovatif dan koloboratif (https://www.edutopia.org/). Pengenalan proses perancangan rekayasa mempergunakan pendekatan pembelajaran berbasiskan projek. Kerjasama erat antara sekolah dan perguruan tinggi yang didukung oleh industri sebagai fasilisator akan mampu memberikan dukungan positif kepada anak-anak yang sedang belajar untuk mengembangkan diri masingmasing.

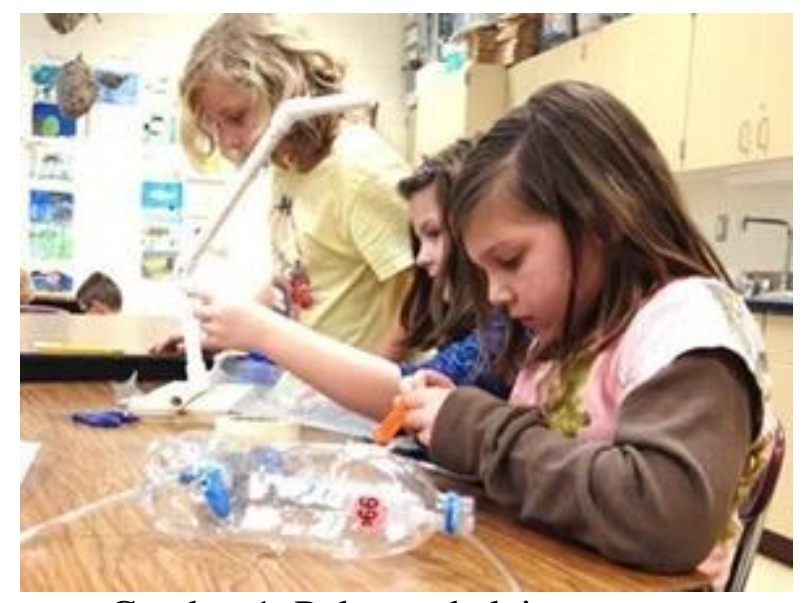

Gambar 1. Pola pembelajaran yang berbasiskan projek

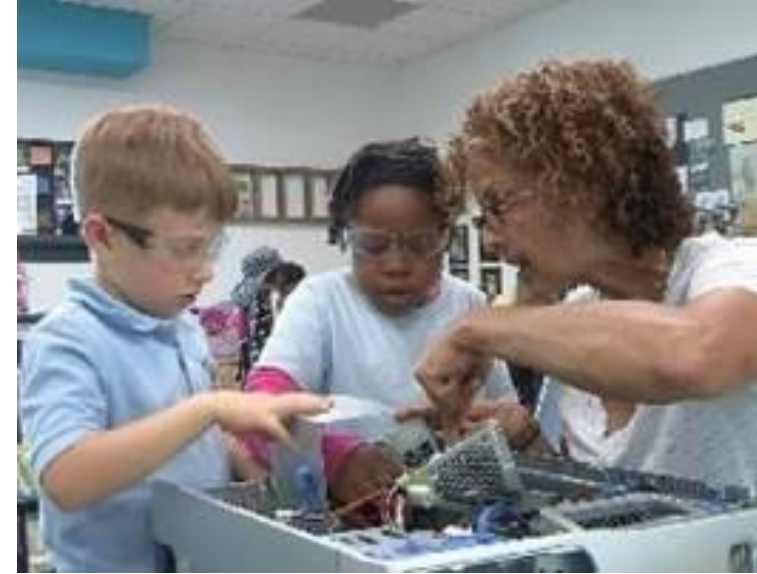

Gambar 2. Mengerjakan projek secara bersama anggota lain didalam kelompok dengan bimbingan guru sekolah

Pada Gambar 1, menampilkan pola pembelajaran yang berbasiskan projek yang sudah sangat dikenal di dunia industri, perlu juga untuk perkenalkan untuk dapat menjadi sebuah pola pembelajaran pada sekolah dasar dan menengah, dengan tujuan untuk melatih siswa dan siswi bekerja secara lebih teratur didalam melakukan tahapan-tahapan proses desain. Pada era industri 4.0, diperlukan pribadi yang mampu berkolaborasi, berkomunikasi dan memecahkan permasalahan. Siswa dan siswi diberikan kesempatan untuk mendapatkan pengalaman dengan cara mengerjakan projek secara bersama anggota lain didalam kelompok dengan tujuan untuk mendapatkan solusi bersama, seperti yang ditampilkan pada Gambar 2.

\section{Adams Middle School}

Sekolah Menengah John Adams menyediakan pendidikan yang beragam dan lengkap bagi pelajar abad ke-21 yang tertarik pada seni dan teknologi digital. Siswa dan siswi akan mengalami kurikulum yang kaya dan beragam yang mengintegrasikan seni dan teknologi digital, serta akan menjadi pemikir yang kolaboratif, kreatif, komunikatif, dan kritis; membuka jalan bagi pengalaman kehidupan nyata, peluang pasca-sekolah menengah, dan kesuksesan karier (https://www.gpisd.org). Sila lihat pada Gambar 3. 

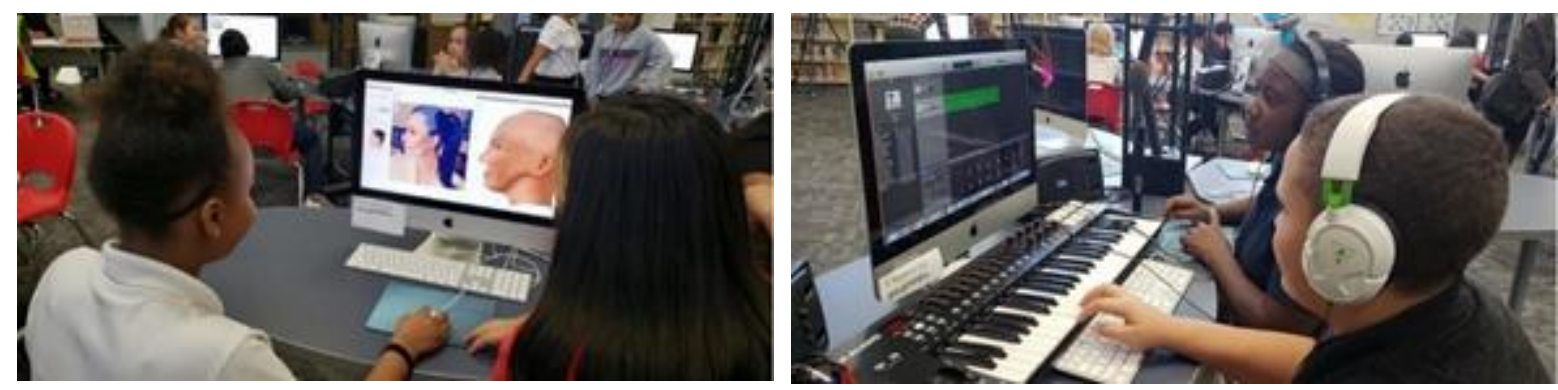

Gambar 3. Konsep pendidikan yang mengintegrasikan kurikulum dan digitalisasi

\section{Jackson STEM Middle School}

Kekuatan para siswa pada Jackson STEM Middle School berfokus pada kemampuan untuk menerapkan Softskill yang dibutuhkan untuk tenaga kerja abad ke-21. Pada Gambar 4 menampilkan proses desain rekayasa sebagai identitas sekolah., selain itu keterampilan kolaboratif didalam mengerjakan projek (https://www.acpsd.net/JMS)
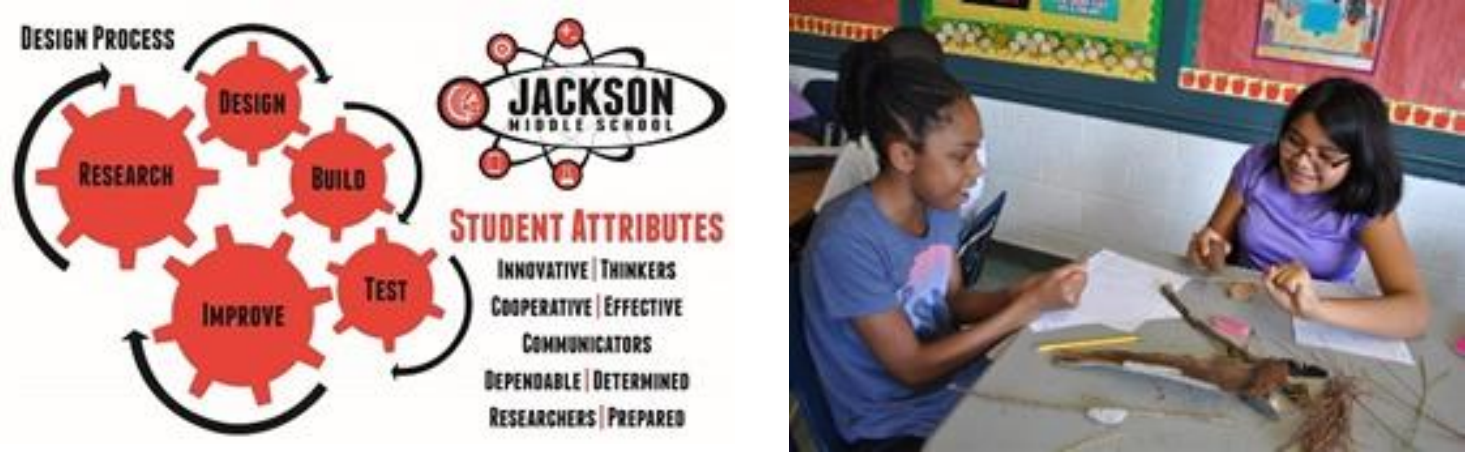

Gambar 4. Proses Desain Rekayasa sebagai identitas Jackson STEM Middle School

\section{METODE}

SMP N 11 Tanjung Pinang melaksanakan proses belajar pada pagi hingga siang hari dan selanjutnya pada hari tertentu dilaksanakan kegiatan extrakurikuler siswa di sore hari. Terletak di wilayah pesisir kota tanjung pinang dan berdekatan dengan daerah pemukiman nelayan kampung bugis. Kota Tanjung Pinang sendiri terletak di pulau Bintan, yang berdekatan dengan pulau Batam dan negara tetangga Singapura dan Malaysia.

Pada Gambar 5. menampilkan lokasi kegiatan TFK yang dilaksanakan di SMPN 11 Tanjungpinang.. Transportasi yang dipergunakan untuk menuju sekolah adalah transportasi darat dan laut. Jarak sekolah yang mencapai $25 \mathrm{~km}$ dari pusat kota tanjung pinang dengan menggunakan transportasi darat, telah menjadikan perahu bermotor masyarakat setempat sebagai transportasi alternatif untuk mengunjungi sekolah tersebut.

SMPN 11 Tanjung Pinang berdiri sejak 1994, namun masih terdaftar sebagai Filial dari SMPN 1 Tanjungpinang. Dengan Surat Keputusan tanggal 26 Oktober 1995 No. 10315/O/1995 maka SMPN 11 resmi didirikan. Pada awalnya sekolah ini hanya terdiri dari 6 ruangan namun sejak tahun 2010, meningkat menjadi 13 ruangan, dan kini mencapai 14 ruangan yang terdiri dari 5 kelas VII, 5 kelas VIII dan 4 kelas IX. Pada Gambar 6 menampilkan keadaan di SMPN 11 Tanjung Pinang saat ini. 


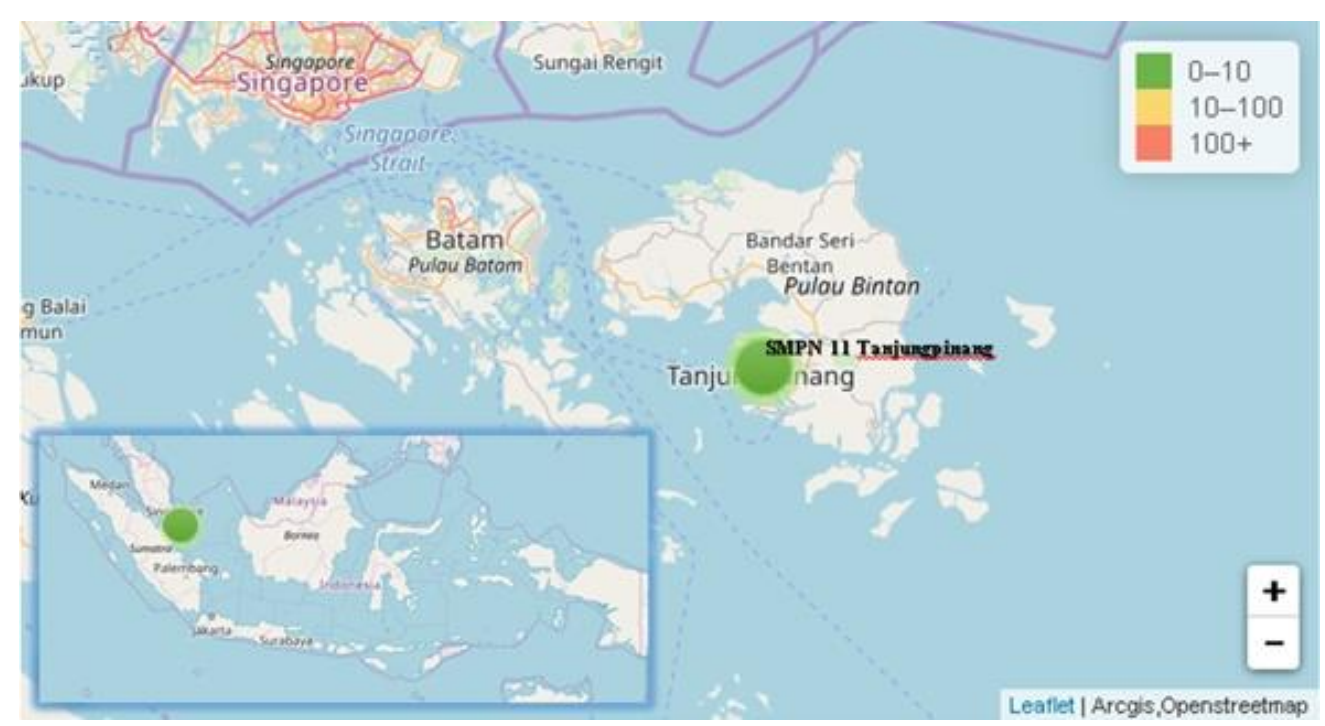

Gambar 5. Lokasi SMPN 11 Tanjungpinang

(http://sekolah.data.kemdikbud.go.id/)

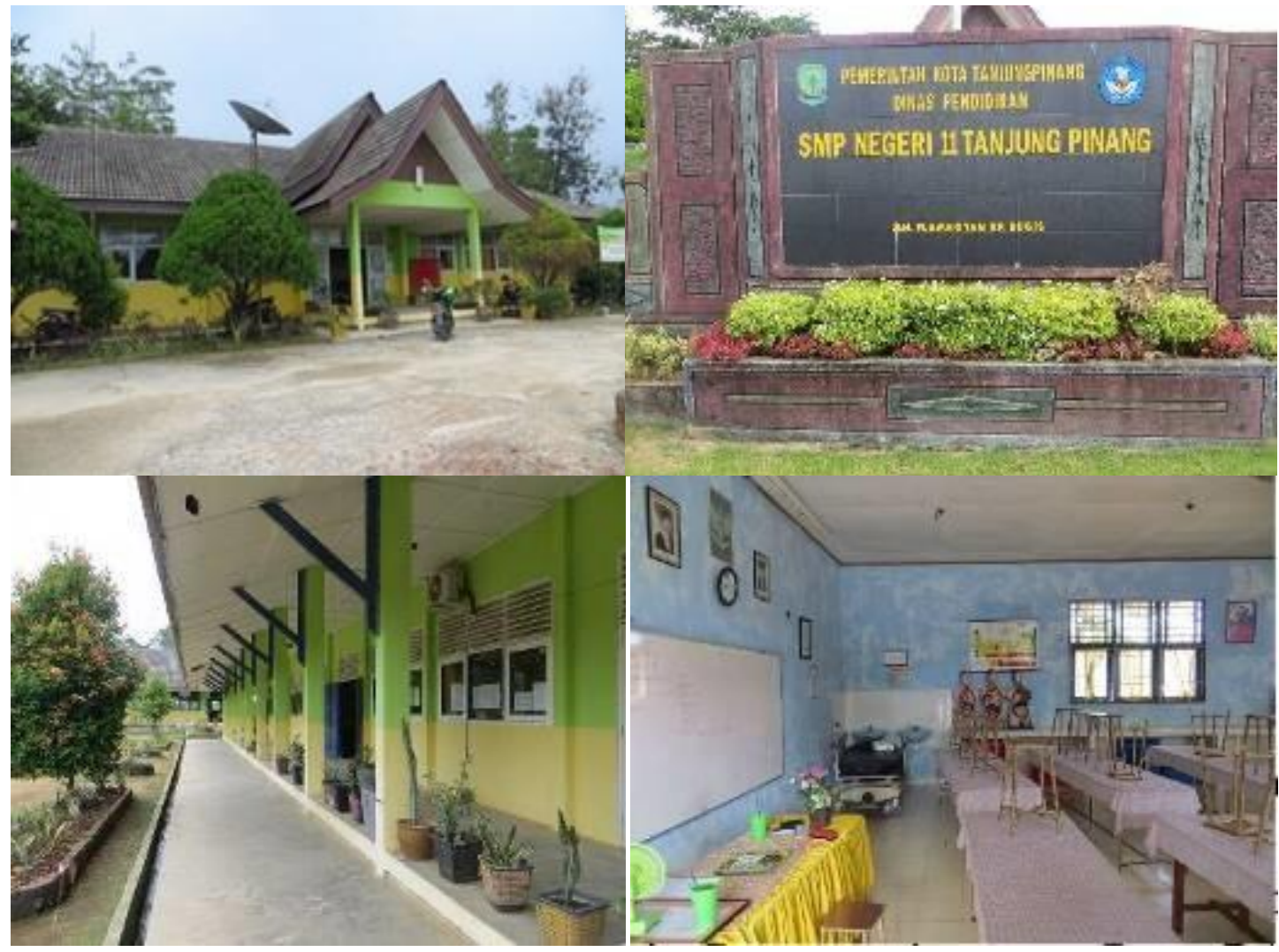

Gambar 6. Suasana di SMPN 11 Tanjungpinang

(http://sekolah.data.kemdikbud.go.id/)

Pelatihan dilaksanakan 1(satu) kali dalam seminggu yang di agendakan pada hari sabtu. Dalam pertemuan pertama diberikan pemahaman kepada siswa mengenai proses desain rekayasa beserta tahapannya. Pada minggu selanjutnya fasilisator pelatihan akan mendampingi siswa dan siswa dalam setiap tahapan hingga menghasilkan luaran pada ahir kegiatan nantinya.

Tech for Kids sebagai latihan pengenalan proses (Deny Nusyirwan) | 163 
Pada Tabel 1 menampilkan Agenda Pelatihan Tech for Kids Tahun 2019.

Tabel 1. Agenda pelatihan tech for kids tahun 2019.

\begin{tabular}{lll}
\hline & Materi & Disampaikan Oleh \\
\hline Pertemuan 1. & $\begin{array}{l}\text { 1. Brainstroming permasalahan } \\
\text { 2. Penentuan masalah utama }\end{array}$ & \\
& $\begin{array}{l}\text { 3. Brainstorming solusi } \\
\text { 4. Sketching ( menggunakan kertas } \\
\end{array}$ & fan pena/pensil) \\
& 5. Menggambar menggunakan & \\
& 6erangkat lunak autodesk inventor pelatihan & \\
6ertemuan 2- & $\begin{array}{l}\text { Mengujian } \\
\text { menghanakan komputer untuk }\end{array}$ & fasilisator pelatihan dan siswa/i \\
5 & menggunakan Autodesk Inventor & \\
Pertemuan & Presentasi hasil pelatihan & Siswa/i \\
ahir & & \\
\hline
\end{tabular}

Adapun nama mahasiswa yang menjadi fasilisator dalam pelatihan dan siswa yang terlibat dalam pelatihan Tech for Kids dapat dilihat pada Tabel 2.

Tabel 2. Data Peserta dan Fasilisator Penamping Pelatihan Tech for Kids Tahun 2019

\begin{tabular}{clll}
\hline Nama Sekolah & \multicolumn{1}{c}{$\begin{array}{c}\text { Dosen } \\
\text { Pembimbing }\end{array}$} & \multicolumn{1}{c}{ Siswa } & Fasilisator pendamping \\
\hline SMPN 11 & Deny & 1. Chris Jhon & 1. M. Abyan Fadillah \\
Tanjung Pinang & Nusyirwan, & 2. Yappe Riadi & 2. Oskar Indra Saputra \\
& S.T., M.Sc. & 3. Reizky Alifa & 3. Irwan Saputra \\
& & 4. Adayah & 4. Afdal Hadi \\
& & 4. Ferry Candra & 5. Alfarizi \\
& & 5. Wafiq Azizah & 6. Mohamed Ezham \\
& 6. Rizky Ardiansyah & & Shah
\end{tabular}

\section{HASIL, PEMBAHASAN DAN DAMPAK}

Kegiatan Tech for kids dilaksanakan secara regular mingguan di sekolah dasar dan menengah di kota tanjung pinang. Beberapa sekolah telah dipilih sebagai awal kegiatan yang selanjutnya akan dikembangkan ke sekolah lainnya. Mahasiswa sebagai pelaksana lapangan akan menjadi fasilisator untuk siswa-siswi di sekolah dalam pelaksanaan kegiatan. Pada Gambar 7 menampilkan suasana ruangan pada pertemuan pertama. Fasilisator yang terdiri dari mahasiswa bersama Guru mempersiapkan keperluan untuk presentasi dan memberikan informasi awal kepada siswa mengenai kegiatan rutin mingguan mengenai proses desain rekayasa.

Setelah selesai pada tahapan awal, pengantar mengenai proses desain rekayasa kepada peserta, maka pelatihan dilanjutkan dengan tahapan berikut. 

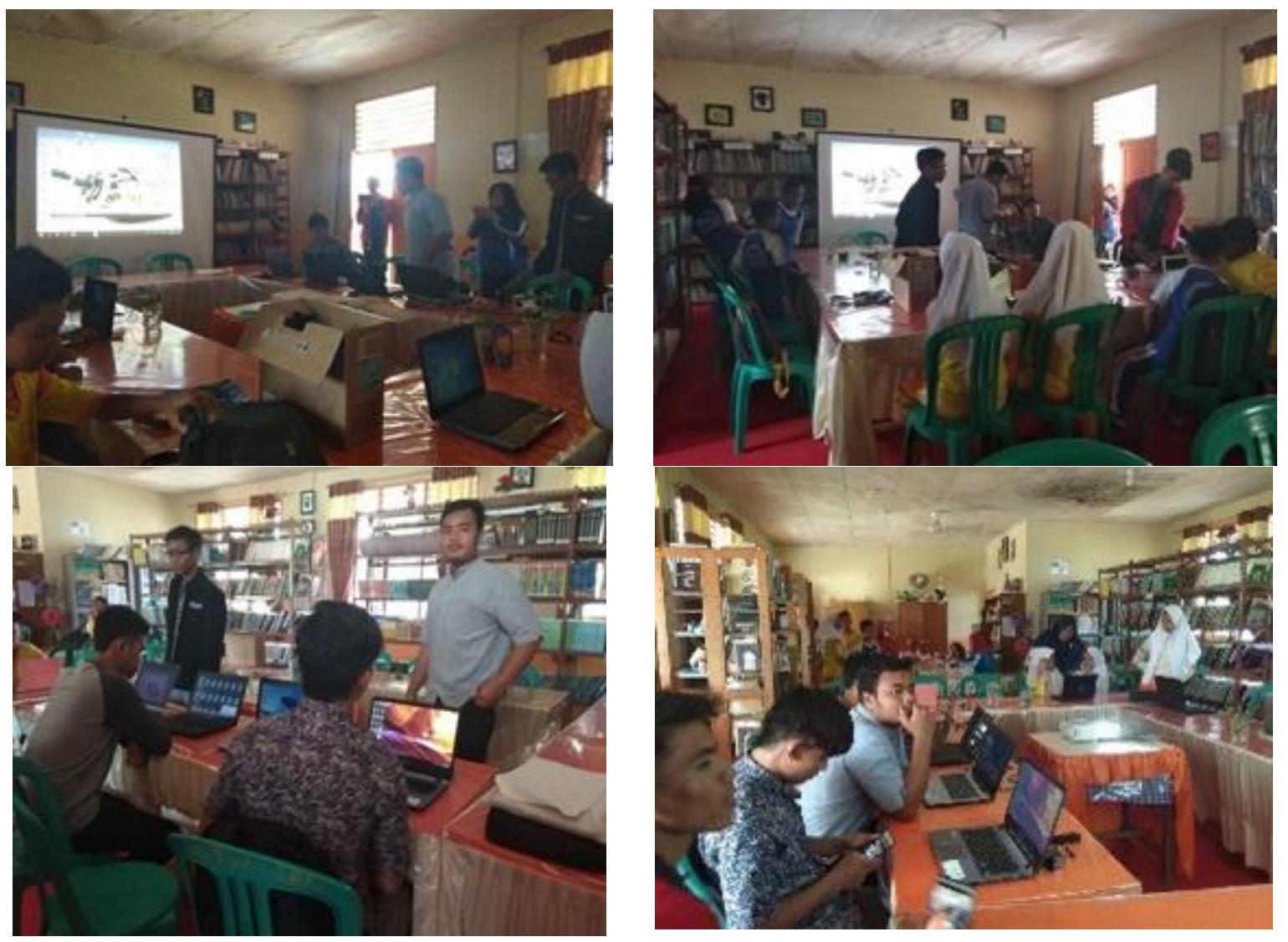

Gambar 7. Suasana ruangan pada pertemuan pertama

\section{Etnografi}

Saat ini teknologi yang dihasilkan adalah merupakan solusi terhadap permasalahan yang ada di masyarakat, oleh sebab itu diperlukan data yang lengkap terhadap permasalahan yang ada pada masyarakat di satu daerah. Untuk itu diperlukan pola pendekatan secara sioal yang dinamakan etnografi.

Etnografi adalah merupakan bagian awal dari Proses Desain Rekayasa, dimana dalam observasi tahapan ini diperlukan pendekatan secara sosial dan memerlukan jangka waktu tertentu didalam pelaksanaannya di lapangan. Pendekatan secara sosial berupa hidup bersama di lingkungan masyarakat dan melakukan aktifitas seperti biasa di masyarakat setempat. Selanjutnya melakukan pendataan mengenai pola hidup masyarakat tersebut yang akan dijadikan sebagai masukan untuk inovasi berbasiskan teknologi Dengan metode observasi yang berbasiskan etnografi, peneliti akan dapat mengumpulkan data secara lengkap dengan melihat dan mengalami secara langsung peristiwa dan kondisi apa yang terjadi, hal ini sangat dianjurkan karena kesulitan yang dialami oleh pengguna untuk mengekspresikan kebutuhan dan keinginan mereka (Blindheim et.al, 2019).Pada Gambar 8 menunjukkan mahasiswa sebagai fasilisator pelatihan berintegrasi langsung dengan siswa, melakukan kegiatan yang sama dan memberikan pandangan-pandangan yang diperlukan untuk melatih siswa dan siswi dalam melakukan observasi terhadap lingkungan sekitarnya. 


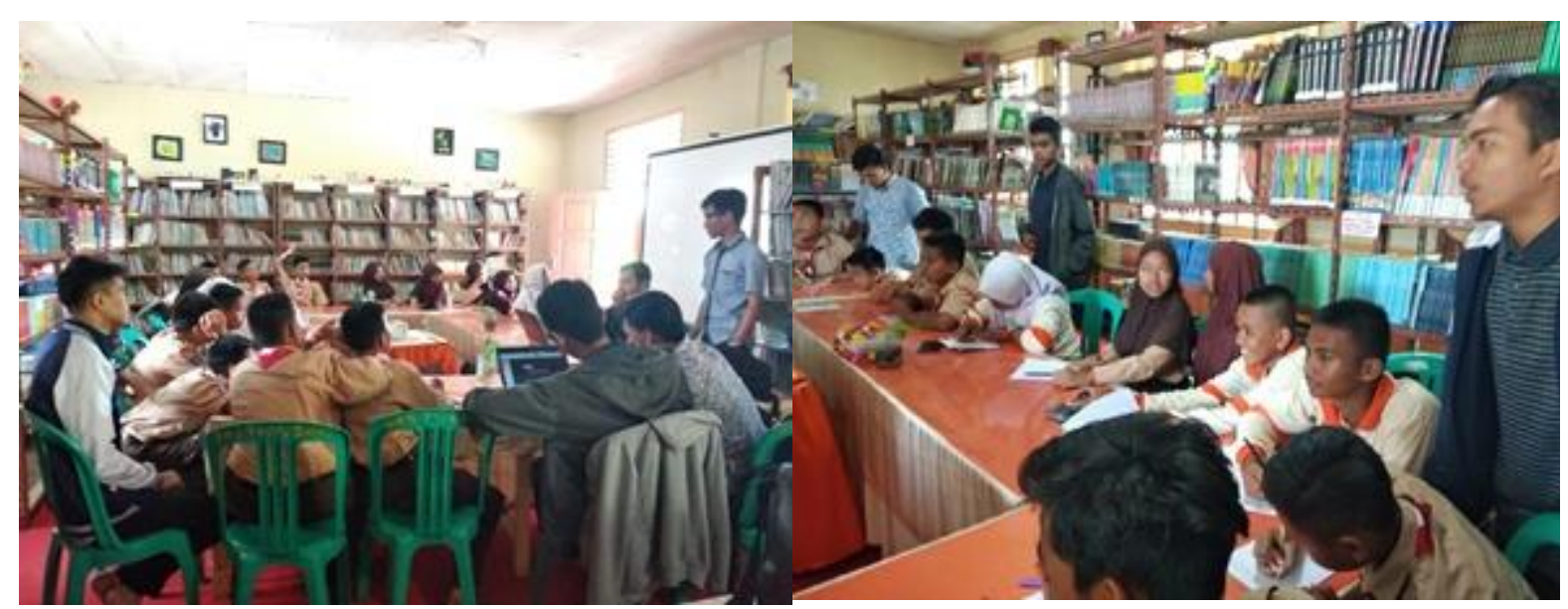

Gambar 8. Mahasiswa berintegrasi langsung dengan siswa tech for kids

\section{Curahan gagasan permasalahan}

Siswa dan siswi melakukan brainstorming terhadap permasalahan yang ada di sekitarnya. Masing-masing siswa menyampaikan secara cepat dengan cara menulis atau menggambar.

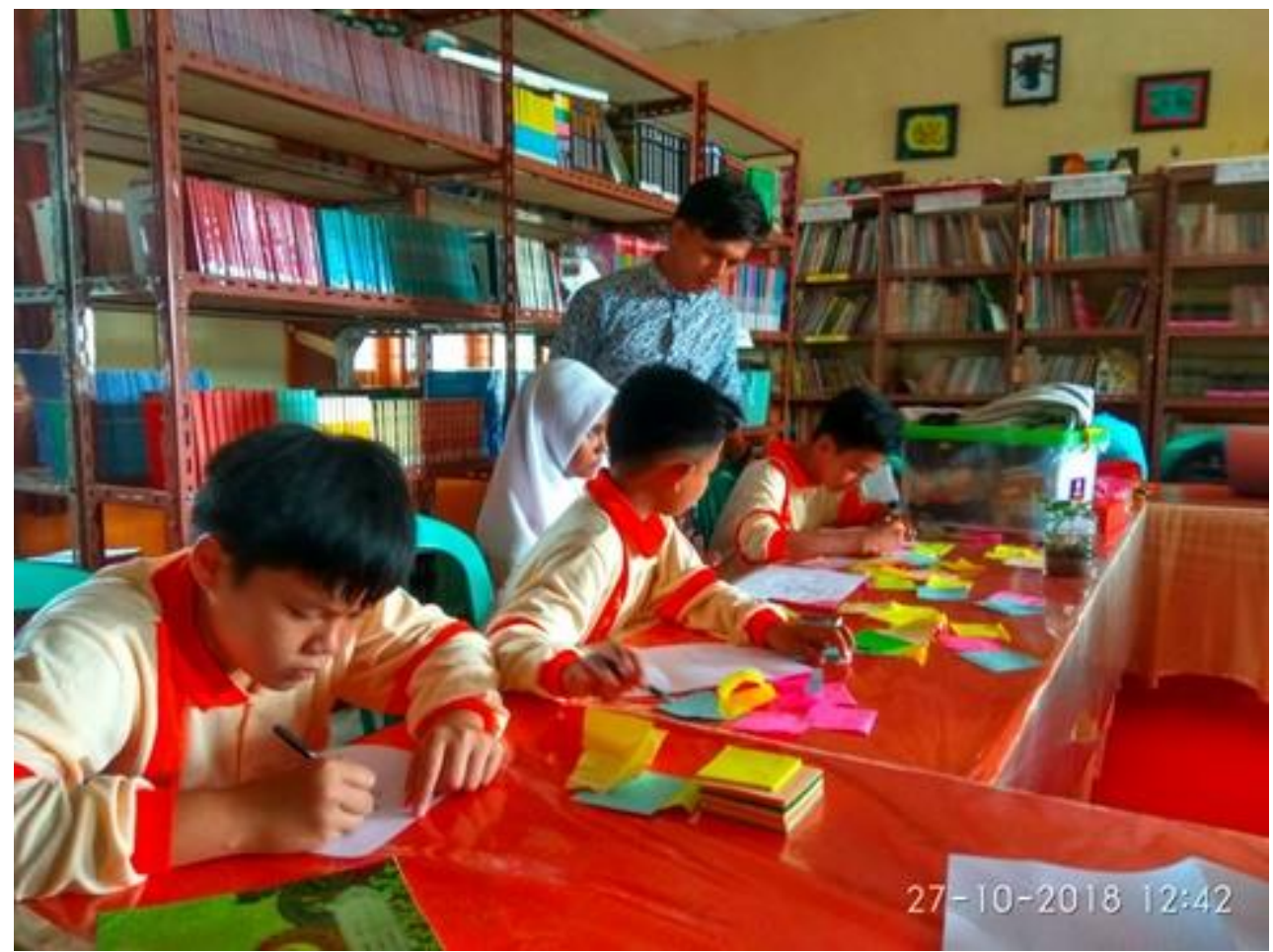

Gambar 9. Siswa dan siswi melakukan curahan gagasan menggunakan post it.

Pada Gambar 9 menunjukkan suasana yang santai dan fun akan menghasilkan dorongan terhadap siswa dan siswi untuk mampu menemukan permasalahan-permsalahan di sekitarnya dengan lebih baik. Fasilisator akan membantu menyediakan peralatan yang diperlukan agar Brainstorming secara cepat. Pola penyampaian gagasan melalui brainstorming sangat diperlukan untuk memotivasi siswa mampu berpikir inovatif dan kratif. Curahan gagasan yang bersifat luas (divergence) adalah merupakan pondasi untuk inovasi yang berbasiskan teknologi, 
hal ini sering dipahami dengan $\mathrm{T}$ concept di dalam bidang rekayasa, dimaksudkan bahwa inovasi yang dihasilkan memiliki pengaruh yang luas dan mendalam.

Adapun aturan-aturan di dalam brainstorming adalah menghindari penilaian secara langsung dan membantah ide yang sedang disampaikan., mendorong adanya ide-ide yang luar biasa/aneh, berpikir seperti anak kecil dimana tidak takut akan kesalahan., mengedepankan kuantitas daripada kualitas., mempertahankan semua pembicaraan dan diskusi serta ide yang disampaikan tetap pada topic dan tidak ada yang berbicara secara bersamaan (Nusyirwan, 2018).

\section{Menentukan permasalahan utama}

Setelah mengumpulkan permasalahan-permasalahan yang ada di sekolah, selanjutnya akan dilakukan pengelompokan untuk menentukan permasalahan utama nantinya. Permasalahan utama adalah permasalahan yang akan di angkat untuk langkah penentuan solusi, dalam tahapan ini akan di pilih satu masalah saja. Proses diskusi bersama sesama anggota kelompok, selanjutnya memberikan penjelasan terhadap masalah yang akan dijadikan masalah utama. Dalam proses ini perlu dipertimbangkan adalah keputusan yang akan diambil adalah merupakan keputusan bersama anggota lainnya.
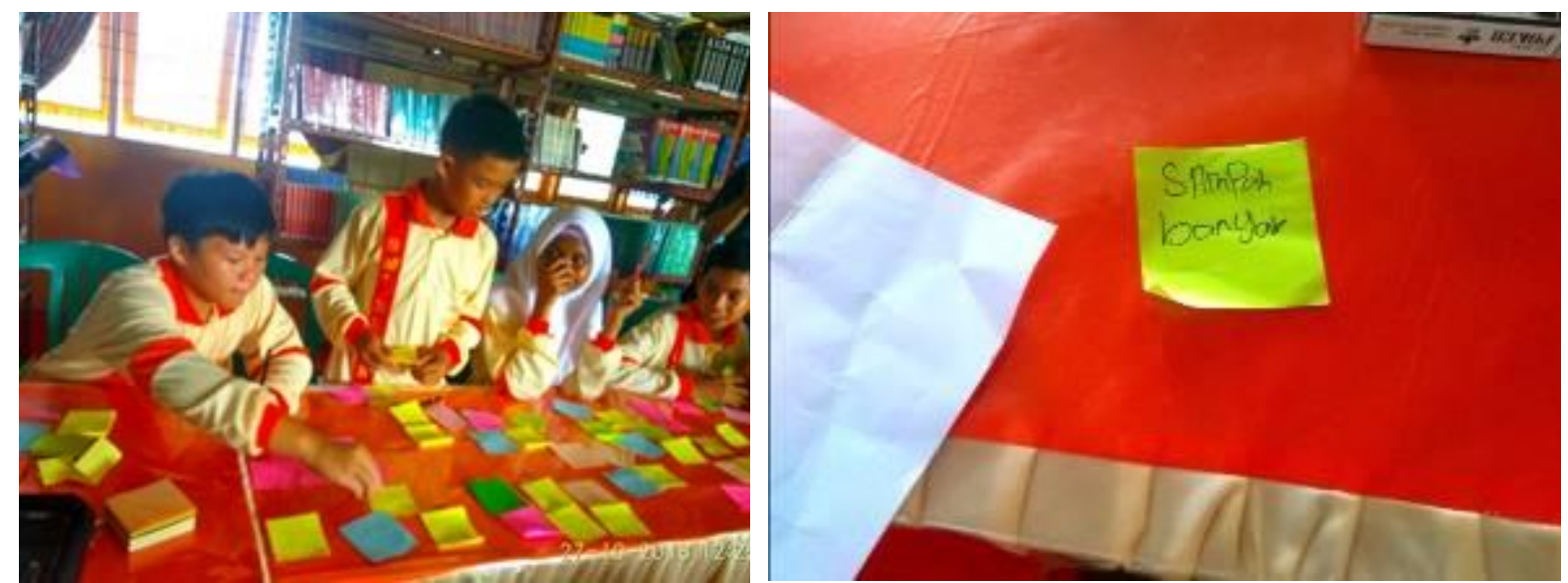

Gambar 10. Pengelompokan yang dilakukan secara langsung sesama anggota keompok untuk menentukan permasalahan utama

Pada Gambar 10 menunjukkan proses pengelompokan yang dilakukan didepan kelas secara langsung sehingga dapat dilakukan diskusi internal kelompok, dimana setiap anggota diminta untuk aktif menyampaikan pendapat.Pada tahapan ini dilakukan proses convergence terhadap permasalahan.

\section{Penentuan solusi}

Tahapan selanjutnya adalah proses divergence terhadap permasalahan utama. Beberapa konsep solusi akan diutarakan melalui proses brainstorming bersama anggota lainnya dengan mempergunakan kertas untuk menulis atau menggambatkan solusi. Pada ahir tahapan ini adalah pemilihan satu konsep solusi yang akan dikerjakan pada tahapan selanjutnya. Solusi utam yang diambil adalah merupakan solusi yang akan berdampak luas untuk masyarakat nantinya. 


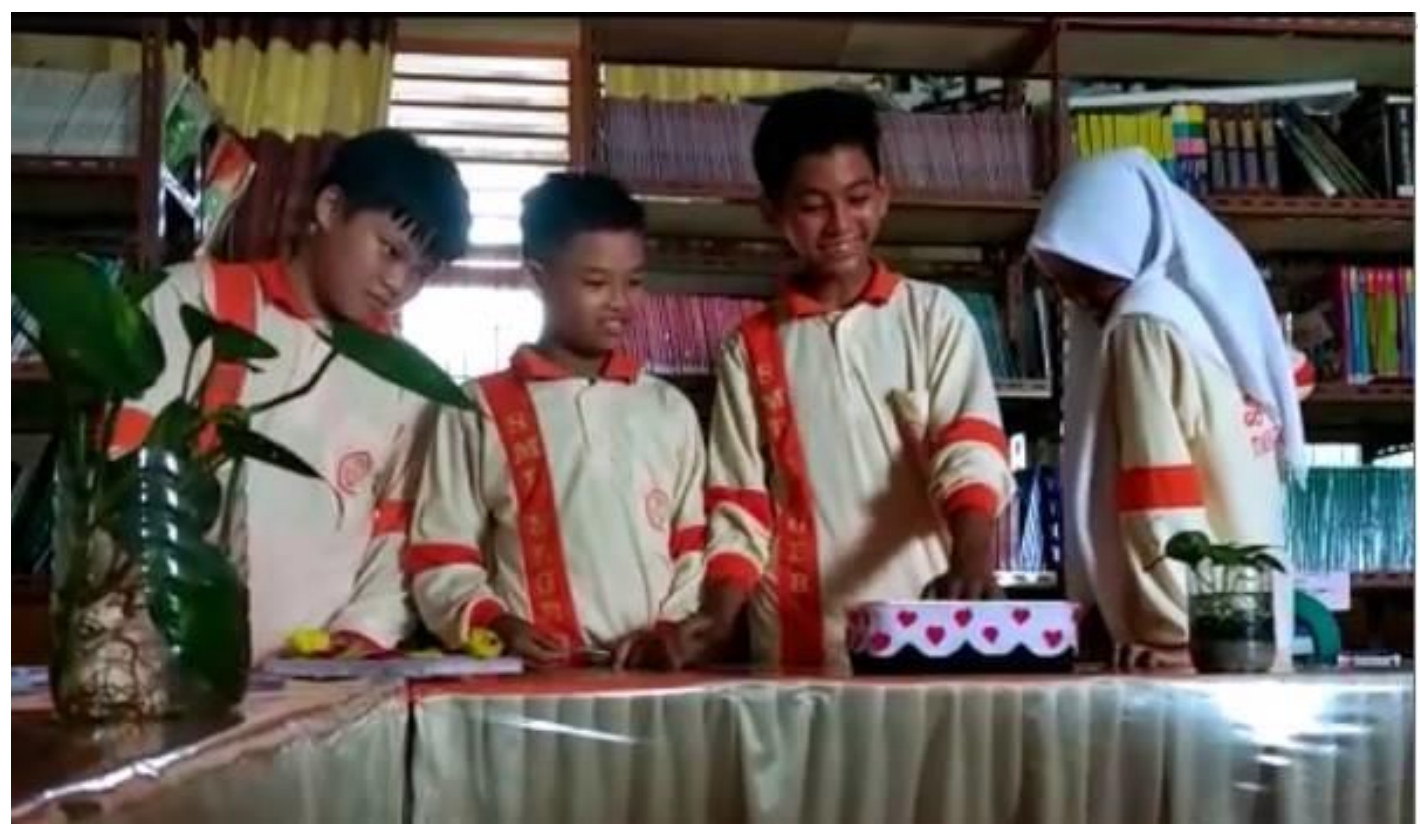

Gambar 11. Proses curahan gagasan untuk mendorong siswa dalam meberikan solusi secara bebas

Pada Gambar 11 menunjukkan proses curahan gagasan kembali dilakukan untuk memberikan kesempatan kepada siswa-siswi untuk berpikir secara bebas menyampaikan pendapat dengan menggunakan kertas. Setelah tahapan divergence solution selesai, maka siswa dan siswi akan menentukan satu solusi yang akan dijadikan sebagai landasan ke tahapan selanjutnya.

\section{Sketching}

Sketching diperlukan oleh siswa untuk mampu mendorong ide-ide yang bisa disampaikan lewat brainstorming. Sedangkan untuk pengguna teknologi, akan dapat melihat konsep awal dari solusi yang diberikan.diskusi secara internal kelompok dapat dilakukan untuk memberikan masukan terhadap rancangan awal. Sangat didorong untuk menggunakan kertas dan pensil karena akan lebih mudah melakukan perubahan jika ada ide lainnya yang akan dikembangkan.

Teknik mensketsa secara manual sesuai untuk menyampaikan ide pada tahapan awal dari penelitian, dimana teknik ini sudah diterapkan oleh perancang (designer) di dunia industri.

Metode perancangan yang menggunakan kertas dan pensil ataupun bahan-bahan pendukung lain sangat dianjurkan untuk menurunkan biaya didalam penelitian. Selain itu tujuan sketsa dalam domain teknik adalah menyediakan komunikasi dan pengambilan keputusan yang lebih cepat pada tahap awal desain, dengan memberikan gabungan visual dan faktual deskripsi untuk peningkatan evaluasi dan pemilihan konsep (Yim dan Lee, 2015). Sketsa desain tidak menggambar sesuatu yang sudah ada, sebagai contoh gambar tokoh, gambar benda hidup dan sejenisnya. Sebaliknya sang desainer terlibat dalam proses berusaha memberikan definisi eksternal kepada sesuatu yang dibayangkan (Tovey et.al, 2003) Pada Gambar 12 dapat dilihat hasil rancangan yang dilakukan oleh siswa.

\section{Purwarupa Virtual}

Dalam tahapan ini, telah dimulai menggambar menggunakan komputer untuk mendapatkan tampilan detil awal secara virtual 3 dimensi.Beberapa perubahan dapat dikerjakan secara langsung. Pada Gambar 13 menunjukkan siswa melakukan proses transformasi dari sketsa yang digambar di atas kertas ke komputer. 


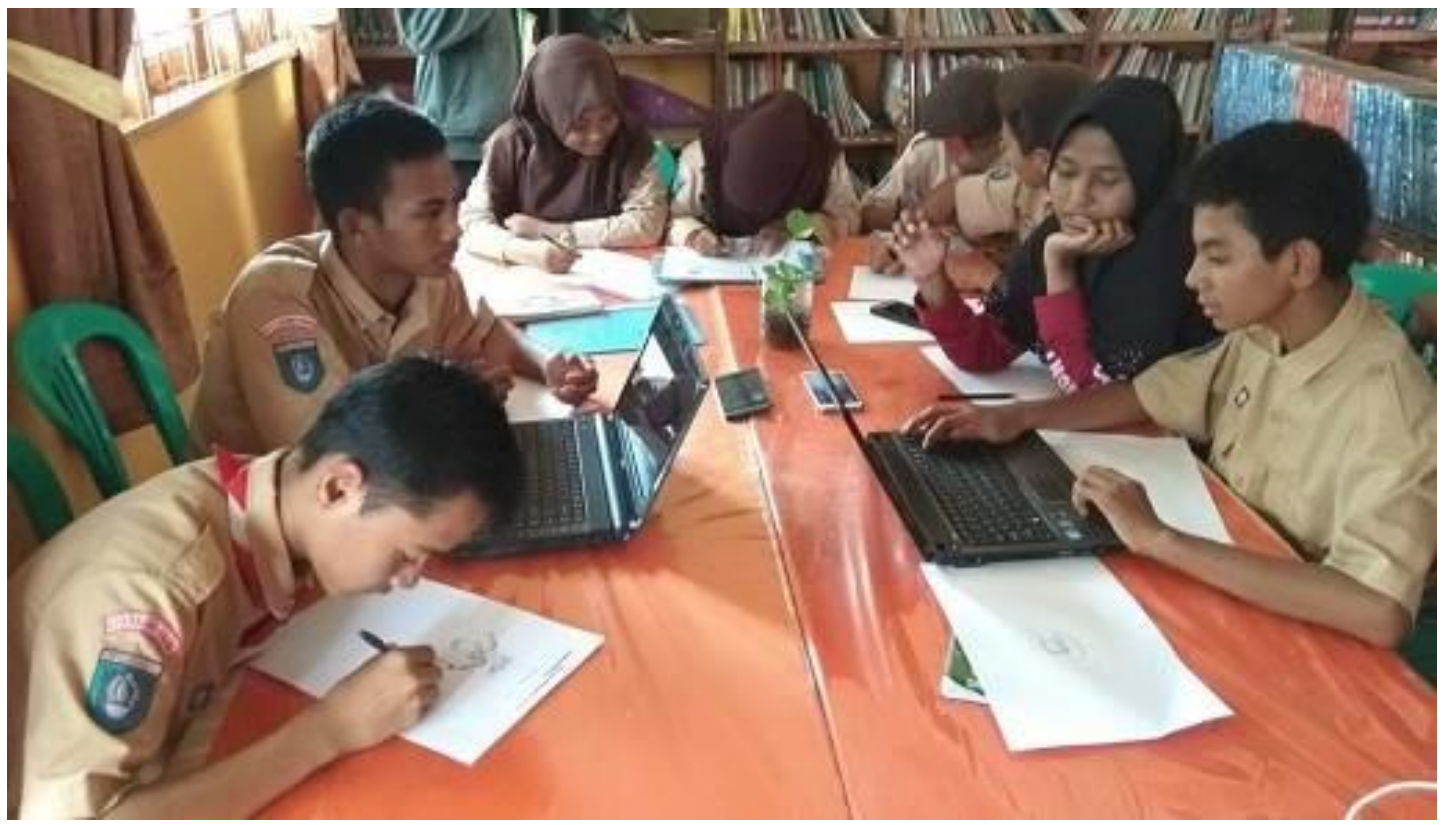

Gambar 12. Mensketsa di atas kertas

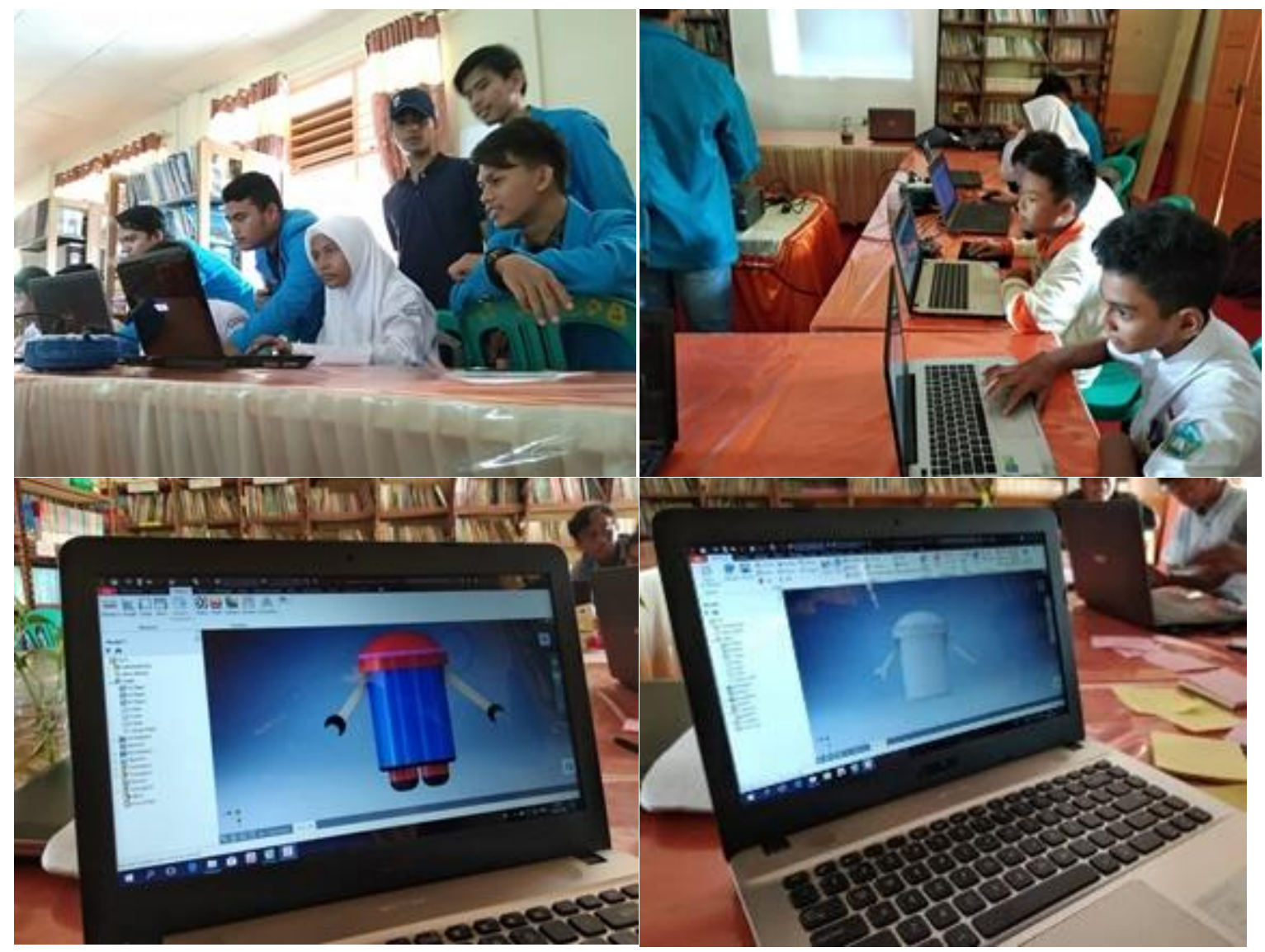

Gambar 13.Pembuatan purwarupa virtual dari hasil sketsa 
Desainer menggunakan model virtual untuk menggantikan purwarupa nyata dan menganalisisnya menggunakan berbagai jenis simulasi yang bertujuan untuk menciptakan kembali kondisi kehidupan nyata di mana produk perlu beroperasi. Proses ini dibantu oleh program komputer modern, yang dibuat untuk membantu para rekayasawan modern dalam pekerjaan mereka. Model virtual dibuat akan mencerminkan gambar nyata, atau sedekat mungkin dengan nyata (Łukaszewicz, 2017). Keuntungan utama dari purwarupa virtual adalah pembuatan purwarupa dari konsep inovasi untuk pengujian awal tidak diperlukan karena setiap penyesuaian akan dilakukan secara langsung dalam realitas virtual dengan mempergunakan simulasi. Purwarupa dapat di explorasi secara virtual dan interaktif, selanjutnya dapat dipelajari dan disimulasikan sebelum implementasi di dunia nyata (Wang, 2011).

Setelah selesai Tech for Kids, mahasiswa sebagai fasilisator memberikan sertifikat pelatihan kepada siswa yang disaksikan oleh Dosen Pembimbing, sila lihat pada Gambar 14.

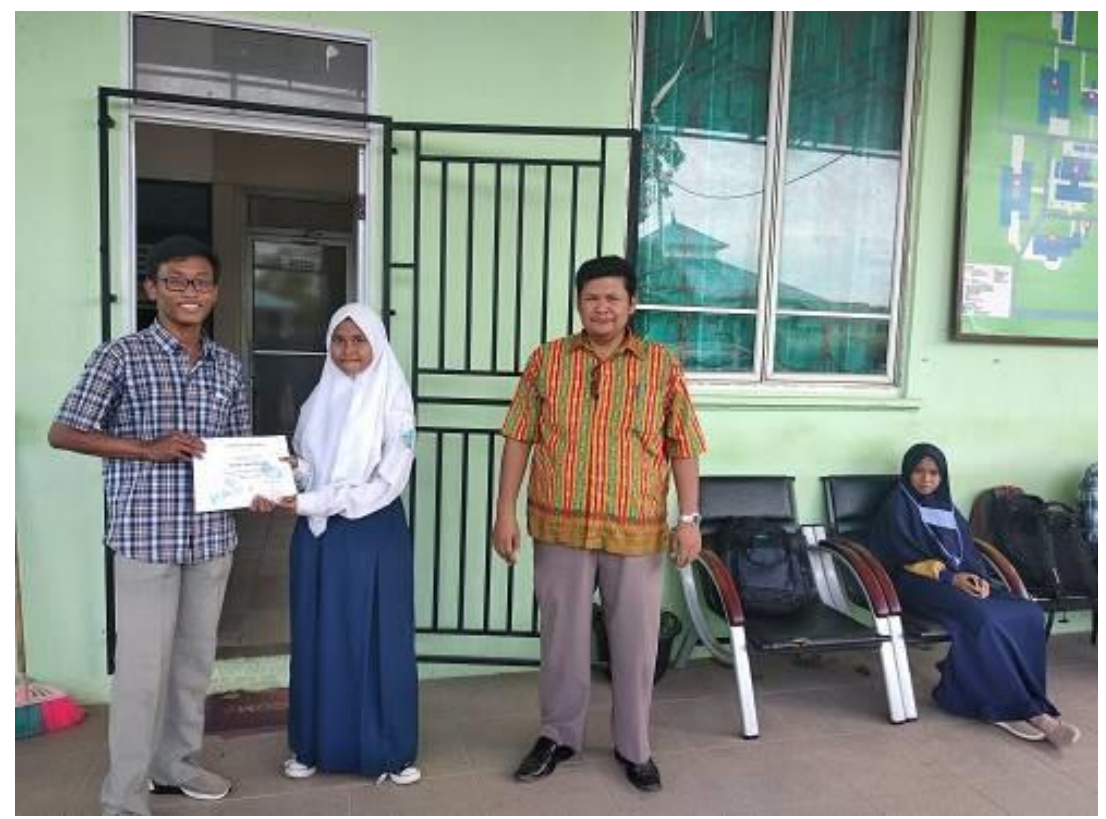

Gambar 14. Fasilisator memberikan sertifikat pelatihan kepada siswa

Kegiatan Tech for Kids, dimulai dengan pelatihan rutin mingguan di sekolah dasar dan menengah telah mendorong siswa dan sekolah untuk meningkatkan pengetahuan dengan penguasaan teknologi dan meningkatakan prestasi siswa di sekolah atau daearah. Kemampuan berfikir secara luas yang diperkenalkan didalam proses pembelajaran TFK, mampu menyadarkan siswa akan pentingnya teknologi. Demikian juga sekolah yang termotivasi untuk mendorong siswa tidak hanya menjadi pengguna teknologi. Meningkatnya keinginan siswa untuk belajar menggambar menggunakan autodesk inventor juga telah menunjukkan keberhasilan dari program TFK.

\section{SIMPULAN}

Tech for Kids adalah pengenalan proses perancangan rekayasa pada siswa sekolah dasar dan menengah. Pelatihan ini dimaksudkan untuk memberikan kemampuan teknis siswa menggunakan perangkat lunak Autodesk inventor untuk menggambarkan purwarupa virtual tiga dimensi. Selain hal tersebut, dengan pelatihan yang diberikan siswa juga diharapkan akan mampu bekerja sama, berpikir kreatif dan memahami proses perancangan rekayasa untuk menghasilkan inovasi teknologi yang merupakan solusi yang tepat bagi permasalahan di 
lingkungannya. Siswa yang mengikuti pelatihan diberikan kesempatan untuk mendapatkan pengalaman dengan bekerja bersama anggota lain didalam kelompok dengan tujuan untuk mendapatkan solusi bersama. Sekolah berharap, Tech for Kids dapat menjadi kegiatan terjadwal untuk kedepannya

Tech for Kids adalah satu bentuk kegiatan pelatihan yang dapat dilaksanakan akibat adanya kerjasama yang baik dengan pihak sekolah, diharapkan untuk kedepannya dapat juga melibatkan pemerintah daerah untuk mengadakan kegiatan serupa untuk memasyarakatkan teknologi pada anak usia sekolah, dengan demikian akan mempersiapkan generasi yang mampu bersaing secara global. Dengan adanya mahasiswa sebagai fasilisator, dapat mendorong siswa untuk lebih antusias didalam memahami materi proses perancangan rekayasa, oleh sebab itu pola seperti ini juga dapat diterapkan di sekolah untuk mata pelajaran tertentu yang mengajarkan ilmu teknik.

\section{UCAPAN TERIMA KASIH}

Terima kasih kepada ketua jurusan dan rekan di jurusan teknik elektro UMRAH serta Sekolah SMP N11 Tanjung Pinang yang telah memberikan kesempatan melakukan Tech for Kids dalam rangka mempersiapkan inovator dan technopreneuer di masa depan

\section{REFERENSI}

Blindheim, J., Wulvik, A., dan Steinert, M., (2016) Using Secondary Video Material for User Observation in The Needfinding Process for New Product Development and Design, International Design Conference - Design 2016

Digital Art and Technology Academi at Adam Middle School [Daring]. Tersedia pada https://www.gpisd.org//site/Default.aspx?PageID=57, [ Diakses : 17 Maret 2019].

Edutopia - George Lucas Educational Foundation [Daring], Tersedia pada : https://www.edutopia.org/ , [ Diakses : 17 Maret 2019]

Jackson STEM Middle School [Daring], Tersedia pada : https://www.acpsd.net/JMS,_[ Diakses : 17 Maret 2019 ].

Kastner, S., dan Knight, R. T., (2017). Bringing Kids into the Scientific Review Process, Neuron, 93(1) : 12-14.

Lucas, B., dan Hanson, J., (2016). Thinking Like an Engineer: Using Engineering Habits of Mind and Signature to Redesign Engineering Education, iJEP, 6(2)

Lukaszewicz, K., (2017). Use of CAD Software in the Process of Virtual Prototyping of Machinery, 7th International Conference on Engineering, Project, and Production Management, Procedia Engineering 182, 425 - 433

Nusyirwan, D., (2018). Design Thinking sebagai Bridge of Innovation Perguruan Tinggi dan Industri di Jurusan Teknik Elektro Universitas Maritim Raja Ali Haji (UMRAH), Jurnal Sustainable, 7(2) : 86-94

Sekolah Kita SMP NEGERI 11 TANJUNGPINANG [Daring], Tersedia pada : http://sekolah.data.kemdikbud.go.id/index.php/chome/profil/007328BD-31F5-E011BF42-F542CFCD811C [ Diakses : 31 Mei 2019].

Tovey, M., Porter, S., dan Newman, R., (2003). Sketching, concept development and automotive design, Design Studies, 24(2) : 135-153

Wang, Z., (2011). Interactive virtual prototyping of a mechanical system considering the environment effect . Part 2: Simulation quality, Comptes Rendus Mécanique, 339(9) : 605-615 
Windl, S. A., dar, M. A., Lingle, J. A., Moore, R., dan Asilkalkan, A., (2019). Exploring student understanding of the engineering design process using distractor analysis, International Journal of STEM Education

Yim, H., dan Lee, K., (2015). Preliminary Modular Design for electric Personal Mobility with Design-Engineering Collaboration, World Electric Vehicle Journal, WEVJ7-0426 